\title{
Cultural and Historical Preservation through Onomastic Materials: A Case of Toponyms and Anthroponyms in Kinyarwanda
}

\author{
Vol: 2, Issue: 8 \\ August/2021 \\ DOI: http://dx.doi.org/10.47742/ijbssr.v2n8p1 \\ https://ijbssrnet.com/index.php/ijbssr
}

\author{
Jacques Lwaboshi Kayigema \\ Department of African Languages \\ University of South Africa \\ Pretoria, South Africa \\ Orcid: https://orcid.org/0000-0002-3525-0398 \\ Email: jacqueskayigema@yahoo.com
}

South Africa

\section{A R T I C L E I N F O \\ Article history: \\ Received: \\ 26 July 2021 \\ 17 Aug 2021 \\ 20 Aug 2021 \\ Revised: \\ Accepted: \\ DOI: $10.47742 / i j b s s r . v 2 n 8 p 1$}

\section{A B S T R A C T}

Proper names, also linguistically called toponyms and anthroponyms, embed extensive sociolinguistic, cultural, and historical aspects in the life of any nation. Thus, they have caught the researcher's attention because of the cultural and historical heritage they preserve in the context of language contact. From one place to another, and one specific period to another, anthroponyms and toponyms offer a wide range of research because of the scientific curiosity researchers have as to know why the name of a person or place exists, where it comes from, who named it, and when it was named so. In other words, the research is carried within spatial and temporal scope. Anthroponymy is the study of proper names of human beings, both individual and collective, while toponymy is the study of proper names of places.

This paper aims at showing how place and person names embed cultural and historical features necessary to understand, explain, and preserve a people's culture and history for a given period. The method used to research this topic is descriptive and it is based on the materials observed from various sources such as street names, hoardings, individual names, just to name a few.

Therefore, this study focuses on specific topologies and periods, i.e. names denoting locations where the Rwandan territory has extended in the precolonial, colonial, postcolonial periods, and post-genocide periods.

Keywords: Onomastics, Toponyms, Anthroponyms

\section{Introduction}

Kinyarwanda is primarily the language spoken in Rwanda, which is a land-locked country on the African continent, $26,338 \mathrm{sq} \mathrm{km}$ in size, and with a population of 13,249,033 as of June 2021. Rwanda is thus the most populated country in Africa with a population density of 525 people per sq $\mathrm{km}$. The country is often given the title "Land of a Thousand Hills", simply because of its fertile and hilly terrain. With an average altitude of 1,600 m above sea level, the country enjoys a temperate climate.

Kinyarwanda is not only spoken in Rwanda, though. It is widely spoken across politically agreed-upon borders in neighboring countries, such as the eastern DR Congo, northern Kivu (Rutshuru, Masisi, and southern Kivu (Uvira, Fizi, Mwenga, Kalemi). In addition, it has spread across to west Uganda (Bafumbira, Gisoro) and north-west (farther to Lake Albert, Rwicanzige, locusts killer), and east Tanzania (Karagwe). This is because the former Kingdom of Rwanda spread over today's Rwanda-recognized territory. In Burundi, the neighbor to the south, it is mutually intelligible with Kirundi, in a similar way Flemish is intelligible to the Dutch-speaking inhabitants of the Netherlands.

Kinyarwanda, like many other languages in contact, has both common and proper names of Bantu origins. These include foreign proper names (loanwords) borrowed from other languages in contact to meet the needs of the daily life vocabulary and activity and mark a specific historical and cultural paradigm shift In this study, it is to be observed that in filling the lexical gap, Kinyarwanda borrowed foreign words extensively, not only out of the need for foreign words but also for prestige.

The variety of proper names in Kinyarwanda trigger a research interest to find out why this has happened, when, and how it happened. Therefore, researchers should carefully study these stems that have morphologically undergone big changes. The data were collected from various sources, including publications, conversations, newspapers, Bible literature, school textbooks, commercial posters, hoardings, oral traditions, just to name a few.

Religion-derived loanwords category represents a wide range of borrowed words from Christendom as well as the Muslim world. Most loanwords have as their primary source, languages such as Latin, Greek, Hebrew, or Arabic. They came into Kinyarwanda via French, English, and Kiswahili. Catholic and Protestant missionaries arrived in Rwanda in the 1900s, especially from Europe and later on from the USA. Each religion used the vocabulary which fits its creed, background, and its way of interpreting the Bible, or else the Quran. Loanwords of this category may help us to understand how, when, and why these missionaries or Moslems came to Rwanda.

Loanwords in this field came alongside the language of influence for a specific religion. The language of influence for 


\title{
International Journal of Business and Social Science Research
}

\author{
Vol: 2, Issue: 8 \\ August/2021 \\ DOI: http://dx.doi.org/10.47742/ijbssr.v2n8p1 \\ https://ijbssrnet.com/index.php/ijbssr
}

Catholicism has been Greek and Latin. Many Latin and Greek words came into Kinyarwanda via French. The same applies to Islam with its language Arabic and Judaism with Hebrew.

Loanwords in this area include proper nouns denoting persons and places. Most borrowed personal proper names (especially given names) come from the Jewish and Christian traditions. They unveil that both Christianity and Islam have heavily influenced the Rwandan culture. People bore foreign personal names because they were forced to take them or because they felt proud of them. It was just a matter of snobbery, prestige, or conformity. Most Rwandans from the two creeds thought that bearing these foreign names would make them look more modern, spiritual, civilized, and cultured. Most of these names came from the Middle East and Europe. They were primarily borrowed from Christian proper names in French. Proper names denoting places were introduced in Kinyarwanda during the colonial period.

\subsection{Problem statement}

The main focus of this study is to research why, how, and how many loanwords derived from proper names have been allocated to different domains of the Rwandan's daily life and have been adapted to fit the nominal class system of Kinyarwanda.

Besides proper names of Kinyarwanda origin, the language has extensively borrowed foreign words out of the need for lexicon. Where loanwords have been borrowed because of prestige there exist doublets. Some specific areas have absorbed more French and English words to cope with the reality of cultural contact. The distribution of proper names in Kinyarwanda observes the noun class system. Thus, loanwords have been allocated to nominal classes which range from 1-16. Interestingly enough, some noun classes have been more hospitable than others. Names denoting persons have been allocated to classes 1 and 2 while those denoting places are allocated to classes 16,17 , and 18 .

A great number of French and English loanwords exist in Kinyarwanda and this indicates the real need to supplement the Kinyarwanda lexicon. Some areas are very likely to absorb more loanwords than others. For example, the area of technology and communication counts more foreign words than any other area. Why are there so many loanwords available in the area of technology and not in agriculture and livestock?

Other scholarly researchers in sociolinguistics have contributed to the study of the language contact between Kinyarwanda and French. Most research studies have been conducted in French so far. However, the current study will also address the contact between Kinyarwanda and English, and unlike the previous publications, this work is written in English to expand the scope of readers and researchers in the area of language contact.

Since a loanword results from languages in culture contact, the study of the historical and social background of that sociolinguistic phenomenon is very essential. The study should take into account the source word and its copy in the borrowing language or recipient language. The original word may be modified to such an extent that it is almost or completely unidentifiable. The work shall be limited to the morphological and semantic aspects of loanwords.

\subsection{Aim of the study}

This study aims to research key areas which have hosted proper names as well as foreign proper names and find out why and how these words fit in the Kinyarwanda noun class system. It will present the coexistence of foreign words with local words, their sociolinguistic and cultural impact. Other languages in a similar sociolinguistic situation in language contact will be addressed to show that Kinyarwanda is not an isolated case but a general sociolinguistic phenomenon.

Although there is no interview envisaged, throughout the research participant observation will be used for the collection of data. The researcher will make use of some written documents and conversations. Thus, the database includes loanwords collected from various written and oral sources such as books, newspapers, plays, Bible literature, reports, school textbooks, commercial posters, signs, hoardings, and conversations. Some other loanwords were picked from the everyday conversation among different groups of people (siblings, students, passengers, colleagues, etc) in contact with the researcher, regardless of whether they were literate or illiterate.

\section{Literature Review}

\subsection{Onomastics}

Speaking of place names, Mills (2016) states that "as soon as one crosses the River Tamar and enters Cornwall the place names change. English place names ending in -ton become few and in their place, one observes a preponderance of Celtic Cornish place names beginning Tre-. Scattered throughout his Survey of Cornwall, Carew (1602) gives various, frequently naïve, interpretations of Cornish place names."

\subsubsection{Proper names: toponyms and anthroponyms before and after 1900}

In the ancient days, places were named after something significant occurred or as a result of a comment made by a prominent traditional leader.

For instance, the naming of Kigali is dated back to the 16th century. Literature with tales of how King Kigeri Mukobanya conquered Buliza and Bumbogo is documented.

In Rwanda, place names will inform on the regional culture, history, dialectal speaking, and geographical aspects. They also tell whether the name goes back to the time before or after colonization, or else after 1994. The latter marks an irreversible trend in the history of Rwanda because of the genocide against Tutsis. Therefore, a paradigm shift is noticed every two periods: 1900-1994, 1994-present.

After 1900, during which time the first European missionaries arrived in Rwanda, there have been new ways of naming: some Kinyarwanda names were given to demonstrate the reliance on God, as a Supreme Being, Sustainer of man's life, or some others were directly borrowed from French, Kiswahili, German, and later on from English. After the 1994 genocide against the Tutsis, names have been borrowed from these languages, whereby an influx of English language elements has entered Kinyarwanda repertoire. 


\title{
International Journal of Business and Social Science Research
}

\author{
Vol: 2, Issue: 8 \\ August/2021 \\ DOI: http://dx.doi.org/10.47742/ijbssr.v2n8p1 \\ https://ijbssrnet.com/index.php/ijbssr
}

This is a normal sociolinguistic phenomenon wherever there is language contact. Regarding borrowing in the bilingual context of Mexicano (Náhuatl), Field (2002) corroborates the researcher's position that a language extensively borrows foreign elements because of the need to fill the gap. He explains:

terms were borrowed en masse to represent concepts that were brought into their world having to do with the imposition of social practices, for example, governmental, military, social, and legal organization along Spanish/European lines), religious customs (according to the spread of the Roman Catholic form of Christianity), occupational (including such aspects of the business as Spanish/European monetary principles, implementation and methods of farming, and so on), and many other cultural accouterments (for example, clothing standards in various official and unofficial areas of life). [1]

Although Kinyarwanda has extensively borrowed from French and English, it has not reached the point whereby borrowing of morphology to the extent that the entire systems are replaced has never been attested in an observable case. The grammatical replacement through borrowing occurs only when there is intensive language contact (Thomason, 1997).[2]

The areas which have adopted loanwords prove that they have been integrated into most of the activities of the daily life of Rwandans. However, Kinyarwanda terminologies denoting activities such as livestock, crafts, pottery, fishery, hunting, and navigation, borrowed very few new terms because there was no real need for them. Rwandans had a great deal of rich vocabulary to express these realities. For example, in Kinyarwanda, more than ten terms are denoting the concept "milk" and that of "cow", whereas English and French may have about two terms.

The current study researches the allocation of proper names in the Kinyarwanda noun class system. Kinyarwanda has hosted a wide range of words from foreign languages over many years from the time it came into contact with other languages. French, English, and Kiswahili have lent more words to Kinyarwanda than any other foreign language. This work will entirely deal with loanwords from Sumerians. This study examines how loanwords have been allocated to the noun classes of Kinyarwanda, a Bantu language spoken in Rwanda and beyond its borders. The research is worth doing because very little has been done so far in the area of loanword adaptation in Kinyarwanda. This sociolinguistic work will be the first of its kind to be conducted in English.

Dubois (1973) explains that a loanword is the most important socio-linguistic phenomenon in a language contact. "L'emprunt est le phénomène sociolinguistique le plus important dans tous les contacts de langues ( $V$. Bilinguisme), c'est-à dired'une manière générale toutes les fois qu'il existe un individu apte à se servir totalement ou partiellement de deux parlers différents." ${ }^{.1}[3]$

A loanword is integrated into any area where the borrowing speaker needs it. Therefore, the primary purpose of borrowing is out of need. However, a loanword can be brought into a language because of snobbery. People borrowing a foreign word imitate something from a foreign country because they think it is more appreciated than theirs. A foreign word sounds more scientific or technical. As with many contemporary loans from English in European languages, such loanwords are simply more fashionable than native words. In the case of Kinyarwanda, loanwords are allocated to nominal classes and begin a new life in a new system of language which has hosted them.

Currently, Rwanda has three official languages: Kinyarwanda, French, and English. In addition to the three official languages and because of the cultural, social, commercial, and political ties that exist between Rwanda and East African countries (Kenya, Tanzania, Uganda), Kiswahili too has been used in commercial centers as a lingua franca, and on the national broadcast radio.

Before Belgians introduced French into a primary school in 1929, Kiswahili had been used to serve as a language of communication in the colonial administration. Most Belgian colonial masters and missionaries of all denominations were using Kiswahili.

As for languages of instruction in secondary education, article 80 of the same decree says that Kinyarwanda and French are the official languages, but that the Minister can authorize the use of another language.

\subsection{Paradigm shift}

English became a third official language just after the 1994 genocide. Its usage in Rwanda has considerably increased for the last two decades. Some schools and establishments use more English than French, while most commercial advertisements use more English than French or Kinyarwanda. Rwanda joined Commonwealth countries in 2009 , i.e. it became its 54 th member; first country to join the Commonwealth under the revised membership criteria, endorsed at the 2007 Commonwealth Heads of Government Meeting (CHOGM) in Kampala, and one of only two members without historic ties to the United Kingdom.

Today it is more prestigious to use English than French in every aspect of daily life: advertising, conferences, telephone conversation, commerce, science, travel, etc. The use of English in advertising (posters, hoardings, signs on commercial house buildings and offices, etc), media, conferences, music, transport, and education is overwhelming. On the other hand, the use of French in advertising, seminars, and offices has considerably decreased for the last two decades. It even sounds old-fashioned to use French in some services.

In an article entitled "Rwandans Say Adieu to Français: Leaders Promote English as the Language of Learning, Governance, and Trade", by Stephanie McCrummen (2008), published in the Washington Post, the reporter highlights Rwanda's current move to English.

In another blow to the language of love, the Rwandan government has decided to change instruction in schools from French to English. All government employees are now required to learn English, and everyone here from lawmakers to taxi drivers to students to businesspeople seems to believe that the 


\title{
International Journal of Business and Social Science Research
}

\author{
Vol: 2, Issue: 8 \\ August/2021 \\ DOI: http://dx.doi.org/10.47742/ijbssr.v2n8p1 \\ https://ijbssrnet.com/index.php/ijbssr
}

usefulness of French, introduced by Belgian colonizers, is coming to an end [...] Most Rwandans speak the local Kinyarwanda language or French. Fewer than 5 percent speak English, although that is set to change. Local English-language schools are filling up with students. It's common to find taxi drivers with FrenchEnglish dictionaries in their glove compartments. Elected officials are dutifully leading the way, sprinkling their speeches with English words, often blended with Kinyarwanda. The other day, a member of parliament spoke of "guporomotinga," or promoting, English. Besides instructional books, the French titles are few mostly cookbooks, such as "Les Vins de la Vigne á la Table," and esoterica, such as "Inventaire des Oiseaux de France," a catalog of birds. Shopkeeper Silas Rwagataraka said he is expecting more customers now that the government is promoting English. "The benefits of learning English are immense," he said, adding diplomatically, "But French, it's not useless at all if you have both languages, you have a better chance of making it." [4]

The importance of a language depends on the position of people who speak it in the international circle of influence. In Kigali city, one may find more English advertisements displayed on various commercial buildings and schools than French ones. It looks as if it is more prestigious to advertise in English than in French, a language which used to be predominant in official documents before 1994. The examples are overwhelming: Alpha Palace Hotel, American Boys Saloon, Apostles Church, Castle Hotel, Centenary House, City Plaza House, Ebenezer Church Full Gospel Businessmen's Fellowship International, Good Look Optical, Gorilla Hotel, Green Hills Academy, Intercontinental Hotel Kigali Business Center, Kigali English Church, Kigali International Academy, Kigali Junior Academy, Kigali Parents School, Kivu Sun Hotel, La Bonne Adresse House, Lutheran World Foundation, MTN RwandaCell, New Texas Saloon, Omega House, Peace House Motel, Preprimary Foundation School, Rubangura House, Isaro Housing Estate, etc.

The coexistence of English and French alongside Kinyarwanda results in various sociolinguistic aspects. One of the sociolinguistic phenomena observed in this coexistence is the influx of French and English loanwords in Kinyarwanda. The latter include deceptive cognates of French and English, which render the use of the three languages more complex. There seems to be a linguistic clash here. The speaker faces a challenge while conversing in either English or French. The understanding of deceptive cognates, false friends, or "look-alikes", would enable the speaker to express his ideas correctly and communicate more fluently. French and English pairs of words having a common origin, whereby the homonym suggests the synonym, are hardly mastered.

Barreteau (1978) states that "Kinyarwanda and Kirundi are, in fact, dialects of the same language.... the differences lie in the intonation and semantics of some words." [5]

Shimamungu (1993) corroborates the same idea but adds a third dialect of the same language. He explains that Kinyarwanda is a Bantu language spoken in Central Africa, in Rwanda. With Kirundi, spoken in Burundi, and Kiha, spoken in western Tanzania, it forms one language of which the three variants are just dialects, and with almost entirely mutual intelligibility. [Le Kinyarwanda est une langue bantu parlée en Afrique centrale, au Rwanda. Elle forme avec le kirundi, parlé au Burundi, et le kiha parlé à l'ouest de la Tanzanie, une seule langue dont les trois variantes ne sont que dialectales, et à intercompréhension quasi totale]. [6]

Commenting on the demographic figures of the population speaking the two variants (Kinyarwanda and Kirundi), inside and beyond their borders, Lyovin (1997) states that Rwanda or Kinyarwanda has $6,205,300$ or more speakers, of whom 5 million are in Rwanda, 867,300 in Uganda, 250,000 in Zaire (DRC), and 88,000 in Tanzania. Kirundi has 5 million speakers, mainly in Burundi, some in Tanzania, and that it is mutually intelligible with Rwanda and is essentially a variant of the same language. [7]

According to Kimenyi (2009), Kinyarwanda, the national language of Rwanda is probably, after Kiswahili the second largest spoken language in the Bantu group. It is a sister dialect of Kirundi, the national language of Burundi, and Giha, another dialect spoken in Tanzania. Despite genocide which took place taking the lives of more than one million Tutsi, its speakers are perhaps more than 20 million people. Rwanda has around 9 million people right now, Burundi has around 7 million but besides the Giha speakers, there are also ethnic Banyarwanda in Southern Uganda in the Kigezi district known as Bafumbira. Other Kinyarwanda speakers are Banyamulenge in Southern Kivu and ethnic Banyarwanda in Masisi and Rutshuro in Northern Kivu in the Democratic Republic of Congo. Kinyarwanda belongs to the interlacustrine (Great Lakes) Bantu languages. ${ }^{2}$ [8]

Kinyarwanda has more than seven dialects inside and outside its borders (DRC and Uganda). Despite minor morphological, semantic, syntactic, and phonological peculiarities in Kinyarwanda dialects, there is mutual intelligibility among Kinyarwanda dialect speakers.

Guthrie (1975) classifies Kinyarwanda as a Bantu language in the linguistic zone D61 and the Tervuren group (Belgium) as a Bantu language in zone J61 (De Blois, 1970).[9]

Nurse and Philippson (2003) combined both classifications and labeled the language JD61. Kinyarwanda is one of the inter-lacustrine languages (Great Lakes region languages), currently spoken by more than 8,5 million in the country alone. [10]

When foreign words are integrated into Kinyarwanda they partially or adopt characteristics of Bantu languages as discussed below.

\subsection{A system of grammatical genders}

Bantu languages have class prefixes, which command the concord. The prefixes or noun markers include nominal, pronominal, verbal, and adjectival morphemes. The nominal morphology of Bantu languages has many noun classes. Their number varies from one language to another, although most of them range from 14 to 24 .

\subsection{A list of common hypothetical roots}

It has a great number of words that may be rebuilt based on fixed rules and may be attached to a list of common 


\title{
International Journal of Business and Social Science Research
}

\author{
Vol: 2, Issue: 8 \\ August/2021 \\ DOI: http://dx.doi.org/10.47742/ijbssr.v2n8p1 \\ https://ijbssrnet.com/index.php/ijbssr
}

hypothetical roots of "Proto-Bantu".

Reconstructed nominal stems and verbal roots are based on fixed rules and share common features with the hypothetical roots of "Proto-Bantu".

In Comparative Bantu (4 volumes), Guthrie (1975) shows that all Bantu languages share the same roots. [10] For example, the verbal root -gend-, "go", is found in almost all Bantu languages, sometimes with variants. Similarly, the nominal stem -ntu meaning "man", "place", and "manner" appears in all Bantu languages and has the same meaning in all of them.

\subsection{Invariable roots of the type $-\mathrm{CV}$ -}

From these invariable roots, most words may be formed by the process of agglutination. In general, the structure of a Bantu language word is -CV- (consonant-vowel). Prefixes, affixes, suffixes can then be added to it to form other words. Comrie (1989) states that "Bantu languages have been long appreciated by scholars for their distinctive morphology, highly agglutinative character and allowing great structural complexity to minimal or even more so to verbal forms." [11]

\subsection{A well-balanced vowel system}

The Bantu vowel system is simple and shows harmony because of the process of assimilation. The vowels of the noun stem or the verbal root influence other vowels within the word. The assimilation is said to be progressive if the vowel which comes after is influenced by the preceding vowel. It is regressive if the vowel which comes first is influenced by the following one. Generally speaking, Bantu languages have five vowels /a e i o u/, except for some languages which have seven. Most interlacustrine languages, the Great Lakes region languages (including Kinyarwanda), have five vowels. [12]

As for the vowel system of interlacustrine languages, Nurse (2003) states most interlacustrine languages have five phonological vowels, with the exceptions in the northeastern extremities $[\ldots]$ and in the southeast, where some speakers of Luhya [...] have, as in JE40, seven vowels, for which we have adopted a unique transcription, /i, e, $\varepsilon, \mathrm{a}, \mathrm{o}, \mathrm{u} /$.

The vowel of the nominal prefix influences that of the augment (in the case of augmenting languages). For example, $u$ $m u-n t u$, "person", a-ba-ntu, "persons", u-mu-ana, "child", $a-b a-$ $n a$, "children" all have vowels in the nominal prefixes and stems similar to those of the augment vowels. [13]

Loanwords were analyzed before deciding which one should be considered as real loanwords (fully or partially integrated). The morphological and etymological criteria to determine which words should be considered as loanwords or not have been used. Most loanwords may or may not take an augment. In some cases, loanwords have zero nominal prefixes. Working on loanword allocation and adaptation in the context of Kinyarwanda, which has no comprehensive dictionary, is not an easy task, though. Thus, relying on the identification of loanwords from informants, even if they are educated, would compromise scientific work. Not everybody can distinguish a loanword from a purely native word, especially when the loanword has undergone phonological, morphological, and semantic changes. The identification and analysis of loanwords require some metalinguistic competence, mainly in morphology, phonology, semantics, sociolinguistics, and etymology.

\section{What is it in the Name?}

There is something powerful in the name, especially anthroponyms and toponyms. A name can display the naming person's emotions, attitudes, ambitions, aims, circumstances, aspirations, chauvinism, background, just to name a few.

Names can sometimes be like trademarks. They become so closely associated in our minds with certain characteristics that when we hear the name we immediately recall these traits. What traits come to mind, for example, when you think of these names: Alexander the Great, Julius Caesar, Nero, Ramses, Kim Jung Il, Adolph Hitler, Isaac Newton, Louis Pasteur, Christopher Columbus, Galileo, Albert Einstein, Martin Luther King Jr., Martin Luther, Kigeli IV Rwabugiri, Mahatma Gandhi, Saul, King David, Dorcas, Napoleon Bonaparte, Nelson Mandela? Just to name a few of them. Each one is associated with certain characteristics and ideals, as in the theory of idea association, which stipulates that when A and B are present in space and time, the presence of $\mathrm{B}$ recalls the presence of A. For example, the names Sir Isaac Newton recall the law of gravitation and the combination of science and theology.

During Bible times, people of the Near East attached great importance to the meaning of names. "The Hebrews always thought of a name as indicating either the personal characteristics of the one named, or the thoughts and emotions of the one giving the name, or attendant circumstances at the time the name was given." Nichol (1978) [14]

For example, names of people in the ancient Near East were not just meaningless ways of identification as often they are to us. To name a girl Mary or Susy does not make much of a difference today. For the ancient Semites, however, human names came heavy-laden with spiritual significance.

With this in mind, it is not so hard to understand why God would want to change Abram to Abraham. Abram means "Father is exalted"; God changed it to Abraham, which means "Father of a multitude." When you look at the covenant promise in which God says "I will make you exceedingly fruitful, and I will make nations of you, and kings shall come forth from you" (Genesis 17:6, RSV), the name change makes better sense. Perhaps it was God's way of helping Abraham trust in the covenant promise, which was being made to a 99-year-old man married to an old woman who had up until that time been barren. In short, God did it to help increase Abraham's faith in God's promises to him.

Misspelling and mispronunciation as a result of chauvinism and prestige

Due to the poor mastery of the lending language, a lot of observations are realized in foreign names adopted into one's language:

For example, in Rwanda, Global English is on the rise and some people think that using English names, will sound intellectual and scientific, to the extent of using misspelled names or words. A few examples of misspelled proper names (with no real meaning) disclose this chauvinism: 


\title{
International Journal of Business and Social Science Research
}

\author{
Vol: 2, Issue: 8 \\ August/2021 \\ DOI: http://dx.doi.org/10.47742/ijbssr.v2n8p1 \\ https://ijbssrnet.com/index.php/ijbssr
}

Odeth, Beatha, Renatha, Donatha, Phiona, Sipha, etc., for Odette, Beata, Renata, Donata, Fiona, Sifa, respectively. Here people think that by fact of using "th" or "ph" the name automatically and ipso facto becomes English.

Name categorization

This research discusses and analyses Kinyarwanda's proper names of persons and places, and additionally, a foreign language derived onomastic loanwords that have been allocated to key areas of influence, especially religion, because they attest certain specific features. They are allocated to key categories such as beliefs, events (death, war, famine, season, travel, etc.), bravery, livestock, farming, etc.

Some examples of anthroponyms (human proper names) denoting beliefs

A few examples, randomly chosen ones, of names related to religious beliefs, illustrate the borrowing from Christianity of Islam beliefs.

Sabato: from Hebrew Chabbat (rest), Sabbath, a Biblical day of worship and rest. It is a name given to a child born on a Sabbath day. This name is very often noticed among Seventh-day Adventist believers who value, in a great deal, this seventh holy weekly day of worship (Isabato, Sabbath, Saturday.

Venusiti: from Latin Venus, Veneris, a Roman goddess of love and beauty, but which was integrated into the Roman Catholic creed. The French name is Vénuste.

Silivesiteri: from Latin silva (forest), a name referring to the forest/bush. The French name is Sylvestre. Some other related names are Sylvie, Sylvanus, Sylvère, Sylveria,

Virijiniya: from Latin, virgo (virgin), name referring to a virgin lady. The French name is Virginie.

Beyatirise: from Latin beare, beo, beatus (bless, I bless, blessed, respectively), a name referring to blessing, happiness. The French names are Béatrice, Béate.

Petero: from Greek Petras (stone), a name referring to one outstanding Jesus' apostle Peter, Cephas, son of Jonah. The French name is Pierre, for the English Peter.

Sitefano: from Greek Stephanos (crown), the name referring to Stephen, the first martyr in the Early Apostolic Church in Jerusalem. It is a reward for the faithful ones in this life, whereas Diadema (diadem, crown) is a decorative wreath-shaped headdress, which refers to a crown worn by a victorious/triumphant king or warrior. The French name is Etienne, for the English Stephen

Imanweli: (Immanuel, romanized: Emmanuel): from Hebrew, meaning "God is with us". It is a name that appears in the Book of Isaiah $(7: 14)$ as a sign that God will protect his people, Israel.

Danyeli: from Hebrew, meaning "God is my judge". It is a name that refers to Prophet Daniel (also the book), whose name was changed by King Nebuchadnezzar to Belteshazzar, meaning "Bel protects his life", during the captivity in Babylon.

Gaburiyeli: from Hebrew, meaning "God is my strength". In the Bible, it refers to angel Gabriel, whom God sent to Zechariah (father of John the Baptist), Joseph and Marie (godparents of Jesus), and Daniel.

Mikayile: from the name Mikha'el, meaning "Who is like God" in Hebrew. It is found in the Old Testament, in the Book of
Daniel, and the New Testament, in the Book of Jude, and the last Book of the Bible, Revelation.

Samweli: a male given name and a surname of Hebrew origin meaning Shem Ha Elohim or "God Heard", Sh'ma Elohim. Samuel was the last of the ruling judges in the Old Testament.

Karitasi: from Latin Caritas, meaning charity, name given to a female child

Ezekeli: a masculine Hebrew language name, meaning "God's Strength." It can be used as both a given name and a surname. Yoweri: a male given name derived from Standard Hebrew, Yo'el, or Yô'ell meaning "Yahu is god", "YHWH is God", or the modern translation "Yahweh Is God".

Some examples of toponyms (place proper names) denoting a land owned by a given people, peace, circumstancelevent

It is difficult to find the meaning and origin of some of these names, given that there is no document, research that has been done in the past, or any other specific method that can be used to understand what all those names mean. However, some of them have known origins and histories, some are from branchrelated Kinyarwanda languages, others are from formerly spoken languages that have not yet been identified in Rwanda, and others have confusing, curious or suspicious expressions. Some of the places have unique names based on history

Yerusalemu: Jer-u-Salem: City of Peace

Ebenezeri: a male given name of Hebrew origin meaning "stone of the help" (derived from the phrase Eben ha-Ezer).

Ububiligi: Belgium

Uburusiya: Russia

Ubusuwisi: Switzerland

Ubudage: Germany

Gabiro: from ku-gaba (verb), donate, it is a stretched plateau place name given to a location in today's Nyagatare District, whereby the Rwandan monarch, King Mutara III Rudahigwa Charles Léon Pierre (March 1911 - 25 July 1959), used to conduct a royal trip and donate cattle and territories to traditional chiefs during the colonial period.

Bweramvura: from $k w$-era (verb), grow, and $i$-m-vura (noun), rain, it is a hilly place name given to a location in today's Gasabo District where it very often rains.

Bwerankori: from $k w$-era (verb), grow, and $i-n-$ kori (noun), edible seed plant, it. is a place name given to various locations in Rwanda. Inkori is an evergreen large shrub or small to medium-sized tree growing to $15 \mathrm{~m}$ tall. Its characteristic round fruits are large, greenish-yellow, have many seeds, and are edible.

Bukinanyana: from gu-kina (verb), play, and $i-n$ yana (noun), heifers, it is a place in north Idjwi island and Masisi in North Kivu (Eastern DRC), denoting the presence of plenty of young cows.

Mburabuturo: from ku-bura (verb), lack, and $u$-buturo (living place), it is a place in some areas of Rwanda, meaning lack of dwelling. The name comes from a certain Serugarukiramfizi who was cast to a hill in Kigali City, which is today the site of the University of Rwanda, College of Business and Economics. It is reported that when he could not find his favorite spicy food, he was cast by his fellow statesmen, 


\title{
International Journal of Business and Social Science Research
}

\author{
Vol: 2, Issue: 8 \\ August/2021 \\ DOI: http://dx.doi.org/10.47742/ijbssr.v2n8p1 \\ https://ijbssrnet.com/index.php/ijbssr
}

he said, "This is not a living place, it is 'Mburabuturo' (non-living place), I would rather live with spicy food.

Kibira: from an old Bantu word i-ki-bira (noun), bush, it is a place for some parts of Rwanda and Eastern DRC.

Gatare: from igitare (noun), rock, it is a rocky place.

Byimana: from I-mana (noun), God, it is a place in Ruhango District (Southern Province) denoting something belonging to God.

Ngendombi: from ku-genda (verb), go, to be dried.

and $m b i$ (adjective), bad, it is a place in Ruhango District (Southern Province), just after Byimana. People have drawn a saying, "When you leave Byimana, you end Ngendombi", signifying that one who abandons his God, starts a dangerous journey/pilgrimage.

Bumbogo: from imbogo (noun), buffalo, it is a place of an administrative entity, Bumbogo Sector, in Gasabo District. It recalls the idea of a place where there was a pasture of buffaloes before it was inhabited by people.

Rwinkwavu: from inkwavu (noun, plural), rabbit, it is a place in the Eastern Province. It recalls the idea of a place where there were many rabbits before it was inhabited by people. In Kayonza District, a large part of it was formerly in Akagera Park. Hunters enjoyed hunting wild rabbits. They were often sent by their wives for meat animals to entertain them on special occasions.

Rusumo: from gusuma (verb), roar, bubble, rumble, and i-sumo, a-ma-sumo (noun), waterfall, it is placed in the Eastern Province, on the west coast of Akagera River, near the Tanzanian border. It denotes a place where the waterfall roars.

Kamiranzovu: from kumira (verb), swallow, and inzovu (noun), it is a small river in the Western Province where elephants are believed to have been drowned and disappeared in the river.

Cyasemakamba: from Semakamba (person's name), it is a place in the Western Province, Ngoma District, Kibungo Sector, Cyasemakamba Cell, Kiruhura Village, where there is a big water tank, i-ki-gega, which gave the Pronominal Prefix Cya(possessive, of) to the name Cyasemakamba, to mean Semakamba's water tank. The background of the location is that the place where Semakamba lived he planted a beech tree, which grew and became a hermit. It came to be destroyed in the 1980s, and a water reservoir/water tank was built there by the state agency ELECTROGAZ (WASAC today). The reservoir now feeds the City of Kibungo.

Kigali: from -gari (adjective), wide, -ki-noun class 7 marker, it is the capital city of Rwanda. The naming of Kigali is dated back to the 16th century. History has it that he was awarded Mount Kigali as the seat of his residence by the King of Bugesera. His successor Mibambwe I Mutabazi, took possession of Bugesera, and the natural region of Bwanacyambwe-South was added to Rwanda. It is believed that when his army conquered the area, he stood up at the peak of one hill and he gazed upon the vicinity and said, 'Uziko cya gihugu ari kigari' literally meaning, 'the place is wide' hence Kigali acquired its name.

Nyamirambo: from i-mi-rambo (noun, pl), dead bodies, it is a place in Kigali City. The name was derived from the fact

that in the ancient monarchical times, this area was the dumping place for dead bodies resulting from the violent battles between the Rwandan monarchies and Banyoro (one of Uganda tribes); in the same rhythm other places bordering Nyamirambo like Akumunigo (ku-niga=choke) got their names.

Sashwara: from séchoir (French, noun), drier, it is a place in Jenda Sector of Nyabihu District where pyrethrum used

Kirerema: from clairement (French, adverb) it is a mountain (Mount Kirerema), in Nyabihu District. The name derives from what a French-speaking foreign tourist said when he was standing on that mountain from where he could clearly (French, clairement). Je le vois clairement (I see it clearly). A Rwandan who had accompanied him heard the pronunciation wrongly and thought the white man was named the mountain where he was standing as "Kirerema".

Bazirete: from base au lait (French, noun), milk collection center, it is a place in Nyakiriba Sector, Rubavu District, Western Province. The name results from the wrong pronunciation of base au lait/bazole/. The mispronunciation of the word was /bazoRete/.

Peyaje: from péage (French, noun), toll, a tax levied on passing certain roads or important public works (highways, bridges, tunnels) and whose recovery is intended to amortize the financing, to ensure the maintenance and development of these roads. It is a place on the highway of Kigali City.

Rwicanzige: from kwica (verb), kill, and i-n-zige (noun), locusts, is the old name of Lake Albert between Uganda and DRC. Traditionally, it was one of the places where the kings of Rwanda were not allowed to cross. One of the reasons why the kings did not go beyond the abyss was that the lake bordering the Kitara region was where the origin of Lyangombe was known in Rwanda and it was he who brought the rite of passage before it had ever been in Rwanda. Those who treated Lyangombe as a king because of the honor they gave him were disgusted with the invasion of the region, as it was an interference in his country. This was because the Rwandans regarded Lyangombe as the king of the people taking part in the rite of baptismal initiation. No king dared to go beyond that abomination. Some of the kings who attacked the area were Kigeri Nyamuheshera. When he arrived at the lake, he stopped there. Another king who arrived at the lake was Kigeri IV Rwabugiri. He had launched an offensive attack in Bumpaka to overthrow a man who called himself Rugaju and called himself the king of Rwanda.

Kicukiro: from i-cukiro (noun), the heap of cow dung/manure, it is one of the three districts that make up Kigali City. The name is said to have come from the presence of many cattle which used to leave heaps of manure there.

Beretwari: from belle étoile (French, adjective + noun), it is a shopping center in the Gisozi Sector, Gasabo District. The name is said to have come from a barbershop that used to be called "Belle Etoile", which the locals call Beretwari, and is immediately named after all the centers.

Rwamagana: from $r w a-$ (preposition), of, and $a-m a-$ gana (noun), hundreds. Today, Rwamagana (District) is the name 


\title{
International Journal of Business and Social Science Research
}

\author{
Vol: 2, Issue: 8 \\ August $/ 2021$ \\ DOI: http://dx.doi.org/10.47742/ijbssr.v2n8p1 \\ https://ijbssrnet.com/index.php/ijbssr
}

of one of the districts that make up the Eastern Province. The person is called. There are subtle and, at times, not-so-subtle name comes from the word "hundreds" based on the number of effects. If someone is constantly called "stupid" or "ugly," and if cattle that used to be there.

\section{Conclusion}

Because of the significance attached to names, names would often be changed to reflect a radical change in someone's life and circumstances. In one sense, however, it is not that hard, to influence how they would view themselves and thus influence even for modern minds, to understand the significance of what a how they would act.

\section{References}

Barreteau, D. (1978). Inventaire des études linguistiques sur les pays d'Afrique noire d'expression française et sur Madagascar. Paris: Conseil International de la Langue Française.

Carew, R. (1969) [1953]. Halliday, F. E. (ed.). The Survey of Cornwall . London: Andrew Melrose

Comrie, B. (1990). The Major Languages of South Asia, the Middle East and Africa. London: Routledge.

De Blois, F.K. (1970). "The Augment in Bantu Languages”. Africana Linguistica 4:85- 165. Brussels: Tervuren.

Dubois, J. (1973). Dictionnaire de Linguistique. Paris: Librairie Larousse.

Field, F. (2020). Linguistic Borrowing in Bilingual Contexts. Amsterdam \& Philadelphia: John Benjamins.

Guthrie, M.. (1975). Comparative Bantu, vol 3. London: Gregg Press.

Kimenyi, A. (2009). Kinyarwanda. California State University at Sacramento [o] Retrieved 19 November 2020 from www.kimenyi.com/Kinyarwanda.php

McCummen, S. (2008). Rwandans Say Adieu to Français: Leaders Promote English as the Language of Learning, Governance and Trade, Washington Post Foreign Service, Tuesday, October 28, 2008. Retrieved on 5 June 2021 from https://www.excelafrica.com/ 2011/02/03/ rwandans-say-adieu-to-francais/

Mills, G. E., \& Gay, L. R. (2016) Education research: Competencies for analysis and applications. London, England: Pearson Education

Nichol, F.D. (ed) (1978). The SDA Biblke Commentary Volume 1, Genesis to Deuteronomy. Maryland: Review and Herald Publishing

Nurse, D. \& Phillipson, G. (2003). The Languages of Bantu. London: Routledge.

Pateau, A. M. and W. B. Barrie. (1998). Les faux amis en anglais. Paris: Le Livre de Poche.

Shimamungu, E. (1993). "Ordre des mots dans la phrase simple et mécanisme de predication en Kinyarwanda". Linguistique Africaine 10: 65-85. Paris: GERLA.

Thomason, S. G. 2001. Language Contact: An Introduction. Washington, D. C.: Georgetown University Press. Retrieved on 15 May $2021 \mathrm{http}: / /$ wwwhomes.uni-bielefeld.de/LgCont-LgDeath (Thomason).pdf. 